\title{
Projected Cross-Laminated Timber Demand and Lumber Supply Analysis
}

\author{
Kristin Brandt, ${ }^{\mathrm{a}}$ Greg Latta, ${ }^{\mathrm{b}}$ Dane Camenzind, ${ }^{\mathrm{a}}$ Dan Dolan, ${ }^{\mathrm{c}}$ Don Bender, ${ }^{\mathrm{a}}$ Alex Wilson, ${ }^{\mathrm{d}}$ \\ and Michael Wolcott ${ }^{a}$
}

The use of cross-laminated lumber (CLT) for building construction has gained interest in the United States (US) and Canada. Although anecdotal market size claims exist, few quantitative studies have estimated the potential market size or discussed the impact of CLT on lumber supply. This paper presents a method to quantify CLT markets and lumber supplies based on data for the Northwest US. The western US was chosen for its early adoption of CLT combined with a long history of commercial timber construction. Structural designs of archetype buildings were combined with projected multifamily residential and commercial building construction to estimate the demand for CLT. These figures were reduced to account for assumptions that address market penetration and population density. In the case study for the Northwest, the total potential market is less than the existing CLT production in western North America. Thus, the demand region was expanded to include the US and Canada west of the Rocky Mountains, resulting in an estimated demand of $800,000 \mathrm{~m}^{3} / \mathrm{yr}$ by 2030 . A regional lumber supply study suggests that the lumber supply will support the existing CLT industry, which utilizes approximately $2 \%$ of the selected lumber classifications, with an unknown impact on lumber cost and production.

Keywords: Cross-laminated timber; CLT; Demand; Lumber supply; Market penetration

Contact information: a: Composite Materials and Engineering Center, Washington State University, P.O. Box 645815, Pullman, WA 99164-5815 USA; b: Department of Natural Resources and Society, University of Idaho, 875 Perimeter Dr. MS 1139, Moscow, ID 83844-1139, c: Department of Civil and Environmental Engineering, Washington State University, P.O. Box 642910, Pullman, WA 99164-2910 USA; d: Formerly of Department of Civil and Environmental Engineering, Washington State University, P.O. Box 642910, Pullman,WA 99164-2910 USA; *Corresponding author: kristin.brandt@wsu.edu

\section{INTRODUCTION}

Cross-laminated timber (CLT) is a mass timber product that was developed in Europe during the 1990s. CLT is comprised of an odd number of cross-oriented layers of lumber typically held together by an adhesive resin. The European CLT market is more mature than in the United States (US), and continued steady growth is expected (Karacabeyli and Douglas 2013; Pahkasalo et al. 2014; Grasser 2015; Espinoza et al. 2016; Clemans et al. 2017). Global CLT production in 2015 was estimated to be approximately 1 million $\mathrm{m}^{3}$ and was dominated by European consumption (Muszyński et al. 2017). Approximately one-third of the European CLT market is residential construction. Although commercial buildings are an increasing market, the second-largest segment is "mediumsize public buildings" (Muszyński et al. 2017).

The US is showing interest in CLT, and four manufacturers recently began producing panels, with at least three others in various stages of planning or construction. There is currently a debate on whether CLT will be adopted in the US to the same level 
that it has been in Europe and, if so, what the timeline for adoption might be. Low-rise buildings (generally 6 stories or less) have been the primary focus of CLT use in Europe, but it is widely agreed that CLT has a major market potential for replacing steel and concrete in mid-rise buildings (Crespell and Gagnon 2010; FPInnovations 2011; Mohammad et al. 2012; Stauder 2013; Grasser 2015; Smith and Larson 2017).

Speculation on CLT becoming a major new product in the US is tempered by a lack of research into market demand. Bédard et al. (2010) completed a comprehensive technoeconomic analysis of CLT and assumed that market penetration would be $1 \%$ of new multifamily construction. This proprietary report was prepared to provide demand numbers to Quebec manufacturers. The demand numbers cover the northeastern US, the northcentral US, and Canada for 2006, 2007, and 2008.

Bédard et al. (2010) provided a range of demand numbers that combine $1 \%$ market penetration, an assumed CLT use factor of $0.195 \mathrm{~m}^{3} / \mathrm{m}^{2}$, and new construction data. A CLT use factor is defined here as the volume of CLT in $\mathrm{m}^{3}$ per $\mathrm{m}^{2}$ of building floor area. Assuming CLT would replace only steel or concrete construction without displacing any wood construction, the resulting demand was estimated to be $16,990 \mathrm{~m}^{3}$ in the Northeastern US, Northcentral US, and Canada. If CLT captured $1 \%$ of all new multifamily construction in this region, regardless of construction type, the demand would increase to $50,970 \mathrm{~m}^{3}$. Additional analyses compared the quantity of CLT from 1-4 story buildings and the amount that would be in 5+ story structures. The majority of the buildings, $83 \%$, were in the 1-4 story range irrespective of material type.

BECK (2015) assessed the financial viability of a CLT facility in northern California for the National Forest Foundation. The target buildings were of broad scope, adding commercial, industrial, and institutional structures to the demand. The analysis concluded that a CLT facility was the most financially attractive investment for wood utilization, beating out oriented strand board, biomass energy generation, and veneer production. They did caution that the market is undeveloped, and the entrance of more CLT manufacturers could oversupply the market in the short term.

Karacabeyli and Douglas (2013) assessed the market by comparing the cost to construct a building shell and merging the cost values with demand numbers in 2010 for buildings 1-10 stories tall. Although Karacabeyli and Douglas believe taller buildings are a future possibility, this conservative assumption was made for the near-term projections. Shell costs for CLT became competitive with steel and concrete at five stories and was a superior financial choice at eight stories. Karacabeyli and Douglas chose to analyze two market share values: $5 \%$ and $15 \%$ of the softwood lumber market used in applications that could potentially be replaced by CLT. These penetration estimates translate to $2 \%$ and $7 \%$ of the total US softwood lumber market. Using this estimation method, the total US demand for 2015 was calculated to be 2.1 and 6.4 million $\mathrm{m}^{3}$, respectively. The bulk of the demand for this analysis was in California, Texas, the East Coast, and the Great Lakes region. The Northwest region, defined as Oregon, Idaho, Washington, and Montana, had an estimated demand of 60,000 and $180,000 \mathrm{~m}^{3}$ in 2015 for $5 \%$ and $15 \%$ penetration levels, respectively.

Clemans et al. (2017) reviewed the ability of the Northwest, specifically Oregon's forests, to meet predicted CLT demands, based on a national demand of 14.4 million $\mathrm{m}^{3}$. They estimated that 5 to $15 \%$ of this demand could be manufactured in Oregon due to the quantity and quality of available forests. However, there is concern that access to this material may be restricted. Current CLT needs can be met, but Clemans et al. (2017) states that if future projections are to be met, additional lumber processing capacity will be 
needed in Oregon and southwest Washington. With three-quarters of Oregon's harvest currently being exported outside the state, a portion of this volume could be consumed locally, but the impact on overall log harvest and price is uncertain.

One of the barriers that is consistently listed is the adoption of CLT into local building codes, which is compounded by the rate at which new codes are adopted. A voluntary CLT product standard, ANSI/APA PRG 320-2018, is complete. The 2015 International Building Code (IBC 2015) includes CLT for buildings up to $25.9 \mathrm{~m}$ tall and references both PRG 320 and design with CLT using the 2015 National Design Specification (NDS 2015). In 2018, the International Code Council voted to recommend mass timber products, which includes CLT, be allowed in buildings up to eighteen stories (Breneman et al. 2019). This change will be included in the 2021 IBC code, but this does not mean that states and cities will use the most recently published building code to guide design and construction in their communities. For example, the most recent IBC code published in 2018 is used by only $32 \%$ of states, and even within these states, municipalities may adopt other codes. Nearly $10 \%$ of states still use IBC versions from 2012 or earlier, including Texas that still uses the 2003 code (ICC 2020). The delay in adoption of new codes could inhibit the uses of CLT. However, some local codes already allow taller buildings to be constructed from CLT, and this move may persuade more local codes to allow wood in traditionally concrete and steel structures. Oregon was the first state to add provisions to their code for mass timber in tall buildings, up to eighteen stories (Hedmond 2018). After Oregon's changes in 2018, Washington followed by amending the code currently used (2015) and the 2018 code that was scheduled to be adopted in July 2020 to include mass timber buildings up to eighteen stories. However, the state also allows for municipalities to opt-out of this change, and the code adoption date has been pushed back to February 2021 (WFPA 2018; WA SBCC 2020). As encouraging as this is for CLT, some states and municipalities will be slow to adopt new codes, meaning that CLT use in these locations will likely be delayed, and predicting the timing of these changes is difficult.

Better information regarding future CLT market direction will facilitate expansions of both demand and supply of the product. The goal of this study is to demonstrate how results from an array of studies can be combined with population projections to provide such information. This study provides demand projections for western North America based on detailed data from the Northwest US. The Northwest US region was selected as the basis of this work for three reasons: 1) it is at the leading edge of manufacturing of CLT in the US, 2) states in the region have adopted code changes to allow the design of tall CLT buildings, and 3) detailed data on projected multifamily and commercial construction is available. The estimated demand numbers are based on projected multifamily and commercial construction, structural building designs using CLT, and population projections that can be adapted different levels of market penetration. The current available supply includes existing mass panel (CLT and Mass Plywood Panels (MPP)) production capacity and regional lumber supply. We further disaggregate supply based on lumber suitability for manufacturing CLT that meets both the building design requirements and the existing product standard, which is compared to the projected CLT demand. The resulting market projections for western North America provide important insights and reduce uncertainty that could form an impediment to expansion of the industry. 


\section{METHODS}

An estimation of future CLT market developments requires combining methodologies from multiple studies with a variety of data sources. We take a top-down approach beginning with future building estimates and work backward to the corresponding required lumber supply. Because the detailed data needed for these estimates are only available for the Northwest US, we begin here and then apply these per capita results across western North America.

Our projection method begins by assigning design characteristics for a set of archetype buildings described elsewhere (Dolan et al. 2019). The projections of building construction for the Northwest US (NPCC 2016) are presented. The total estimated demand is then determined by assuming a rate of CLT market penetration (Beyreuther et al. 2016) and applying Northwest US per capita CLT consumption to expand our demand estimates across western North America.

The supply analysis begins with an inventory of existing production facility locations and capacity estimates. We conclude with western North American lumber supply expanded to include both lumber grades suitable for CLT production as well as those co-produced grades that do not meet these specifications.

\section{CLT Demand}

\section{Archetype building CLT requirements}

Estimating CLT use in buildings is based on a range of assumed CLT use factors, defined as the ratio of the volume of CLT required $\left(\mathrm{m}^{3}\right)$ to the building area $\left(\mathrm{m}^{2}\right)$. For this study, building designs detailed in Dolan et al. (2019) provide the structurally required quantity of CLT for a matrix of building geometries with footprints from 93 to $9290 \mathrm{~m}^{2}$ and heights that range from 1 to 20 stories.

Each archetype building was designed to include CLT in all floors and the roof. In addition, for buildings with twelve or fewer stories, CLT shear walls were deployed to resist the required seismic load based on location-specific requirements for Seattle, Washington. However, for buildings with 13 or more stories, a concrete core was employed to resist lateral forces. No volume of CLT is assumed for partition walls, as conventional light-frame construction would provide a less expensive option. The CLT use factor was computed as the amount of CLT required for each archetype building divided by the total area of the building, yielding the volume of CLT per square meter of floor area in the building.

For this paper, the CLT use factor is listed as the total required CLT per unit area $\left(\mathrm{m}^{3} / \mathrm{m}^{2}\right)$ unless it is specified as a sub-divided factor to quantify the amount of each of CLT thickness: 5-ply, 7-ply, or 9-ply. All floor and roof CLT panels are assumed to be 5-ply. This assumption leads to the CLT thickness being the major contributor to the total projected demand in this assessment. For buildings 3-12 stories tall, a combination of 7ply and 9-ply CLT is required for the walls. Shear forces are resisted by 5-ply CLT for one and two-story buildings. CLT use factors for the matrix of archetype buildings are shown in Fig. 1, which illustrates the building archetypes that utilize the most CLT and are likely the target market for producers are 7-12 story buildings. The least CLT is used in buildings with more than 13 stories as these buildings use CLT only for structural diaphragms and not to carry the lateral forces to the foundation. 


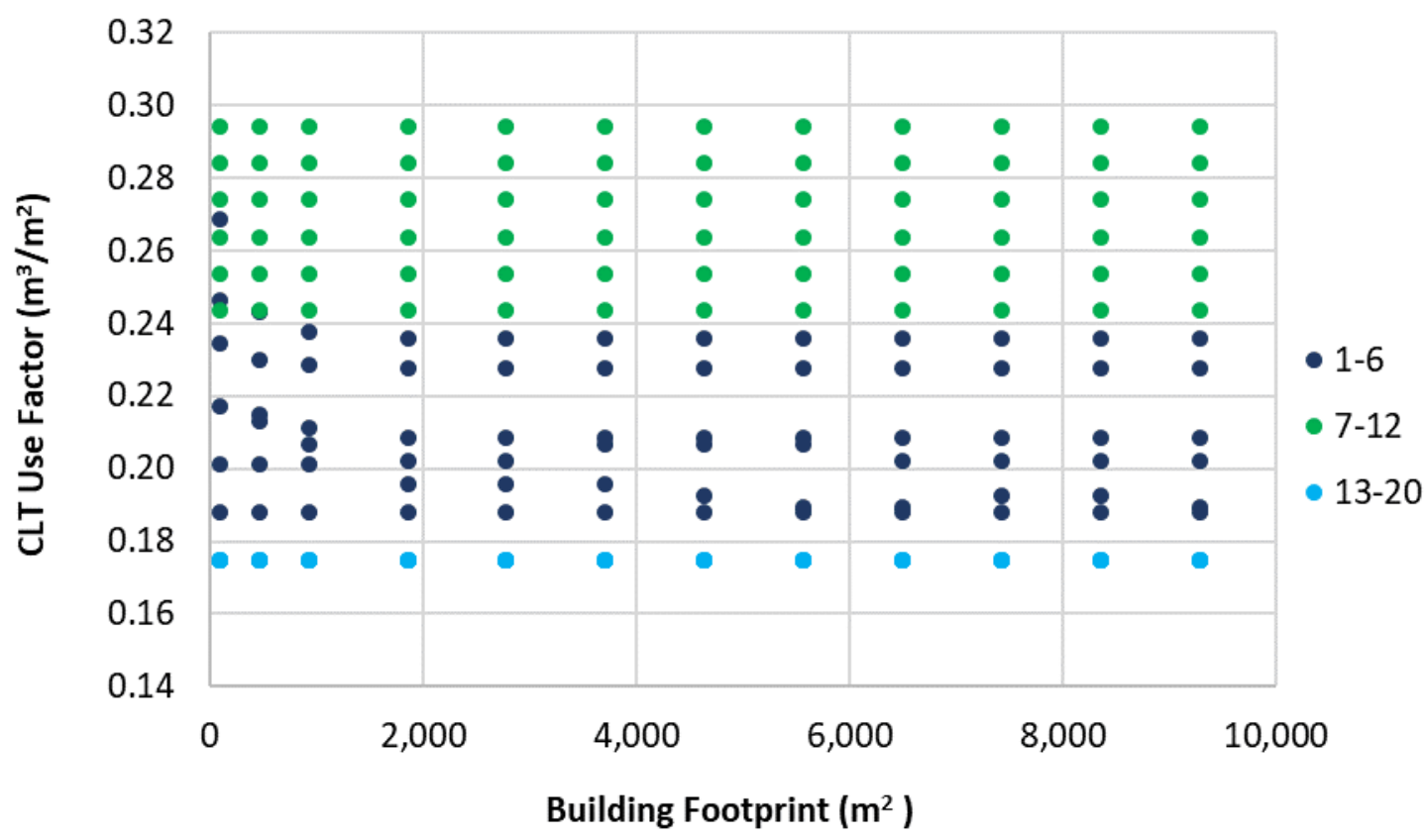

Fig. 1. Total CLT demand use factor for archetype buildings by footprint and building height classification in stories

\section{Archetype building projections}

The Seventh Northwest Conservation and Electric Power Plan (7PP) provides historical data and future projections of new residential and commercial buildings for Idaho, Montana, Oregon, and Washington as part of the planning process for future power needs in the Northwest region (NPCC 2016). The residential market data provided by the 7PP is subdivided into three categories: (1) single-family homes (four units or less), (2) low-rise multifamily homes (1-3 stories with 5 or more units), and (3) high-rise multifamily homes (4 or more stories and 5 or more units). For each type of residential unit and state, the 7PP provides counts of both new and existing units starting in 1985 with projections through 2035 (NPCC 2016). Commercial building data are reported for the same timeline as new building area, with the area partitioned into eighteen building type categories that are a combination of size and end-use, eight of which are included this study's predicted demand. CLT use factors were calculated for the selected residential and commercial building types included in this study using the structural designs completed by Dolan et al. (2019), shown in Table 1.

\section{Multifamily residential buildings projections}

For this assessment, the demand for CLT in residential markets was assumed to be from new multifamily units; no single-family structures were included. This assumption aligns with Grasser (2015), who stated that CLT was more likely to be cost-competitive with traditional construction methods in multifamily buildings compared to single-family or manufactured homes. NPCC (2016) reports new multifamily homes as units, which was converted to area to align with the CLT use factors for each archetype building. This was accomplished by applying the average 2015-2035 area to the quantity of low and high-rise units provided by the 7PP. Each multifamily low-rise and high-rise unit are $77 \mathrm{~m}^{2}$ and 108 $\mathrm{m}^{2}$, respectively. These values were increased by rise-specific, non-residential area factors from Northwest Energy Efficiency Alliance (NEEA 2015). Specifically, the unit size was 
increased to include common areas and other non-residential areas. This ensures that the total building size was estimated for a complete CLT demand estimate.

The adjusted unit size was used to determine the number of units represented by each archetype building. All buildings with fewer than five units were eliminated from the analysis per the NPCC (2016) multifamily residential definition. All $93 \mathrm{~m}^{2}$ footprint buildings were eliminated for high-rise buildings, as the footprint was smaller than a single unit. For applicable archetype buildings in either the low or high-rise categories, the corresponding CLT use factors were averaged across building geometries into a composite CLT use factor (Table 1.) The composite CLT use factors were applied to the average projected areas for the 2015-2035 7PP 2018 data (NPCC 2016). The total demand for each state was sub-divided by the amount of 5-ply, 7-ply, and 9-ply CLT required for the residential market.

With current construction costs, CLT use in low-rise multifamily construction is not likely, especially for one and two-story construction. However, three-story multifamily construction could use CLT. To address the uncertainty in this building classification, two demand scenarios were considered: 1) no low-rise multifamily construction and 2) onethird of the low-rise multifamily demand. The second scenario assumes that one-third of the low-rise multifamily units are in three-story buildings and are a potential CLT market.

\section{Commercial buildings projections}

Demand numbers for the commercial building market are provided by the 7PP as the amount new building area in each of eighteen categories (NPCC 2016). Not all categories were included in this CLT demand analysis. In this paper, researchers chose to include: large, medium, and small offices, educational buildings which are divided into K12 schools and university buildings, assembly buildings, other healthcare, and hospital buildings. Combined, these categories represent 54\% of the new construction of commercial buildings built in the Northwest US. Future work should include an in-depth review of the building classifications not included to determine additional potential markets and the corresponding increase in demand.

The amount of CLT required for each building type was determined by applying the CLT use factors for the appropriate archetype building to the average new area of each building type in each state. A CLT use factor was calculated for each commercial building category. For small offices, which are defined as one-story offices that have up to $465 \mathrm{~m}^{2}$, CLT use factors were averaged for the two archetype buildings meeting that criteria. Similarly, for medium-sized offices, the use factors for archetype buildings with a total area of 465 to $4645 \mathrm{~m}^{2}$ and building heights of 1 to 4 stories were averaged. Large office buildings were defined as over $4645 \mathrm{~m}^{2}$ that were two or more stories tall; these were the use factors that were averaged for this category. The office building sizes were defined by 7PP and heights were calculated using projected building rates, office class sizes, and the breakdown of building heights provided by NEEA (2015).

For grades K-12 educational buildings, CLT use factors were averaged for all 1 to 3 story archetype buildings, which covers $99 \%$ of existing schools in the region (NEEA 2015). University buildings are not explicitly excluded from "schools" by NEEA (2015), but it was assumed that university buildings have a different size and height profile. The $20^{\text {th }}$ Annual College Construction Report gives the mean size of university buildings as nearly $5203 \mathrm{~m}^{2}$ (Abramson 2015). Using this information, the CLT use factor was assumed to be the average of all archetype buildings with one to six stories with footprints of 465 to $9290 \mathrm{~m}^{2}$. In addition, buildings with footprints between 465 and $1858 \mathrm{~m}^{2}$ for heights of 
seven to twelve stories were included.

Assembly buildings are a varied category. An assembly building is defined by NEEA (2014) as a "secular, religious, and cultural gathering place," and the size statistics from NEEA (2015) demonstrate the diverse uses. The mean size of an assembly class building is nearly $1765 \mathrm{~m}^{2}$, which is greater than the third quartile size of $1579 \mathrm{~m}^{2}$. A mean value that is greater than a third quartile value demonstrates a wide range of sizes for assembly buildings. To determine an assembly building category CLT use factor, it was assumed that the buildings are one to six stories tall and the footprint is 93 to $2787 \mathrm{~m}^{2}$. Within this range, the archetype building CLT use factors were averaged.

A similar set of area statistics was provided for the "other health" category. The mean, median, and third quartile sizes for "other health" are 2397, 1133, and $2230 \mathrm{~m}^{2}$, respectively (NEEA 2014a). To accommodate these statistics, it was assumed that "other health" buildings are one to nine stories tall and the footprint is 93 to $929 \mathrm{~m}^{2}$. Within those categories, the CLT use factors from the archetype buildings were averaged.

The final category included in the commercial analysis is hospitals. Data on average hospital size and height is sparse, and each source covers a finite region. However, after researching hospital sizes, it was assumed that hospitals are two to eight stories tall and the footprint is 929 to $5574 \mathrm{~m}^{2}$. As with the other building categories, the CLT use factors were averaged over the range of assumed possible archetype buildings.

Table 1. CLT Use Factors for Residential and Commercial Building Classifications in $\mathrm{m}^{3} / \mathrm{m}^{2}\left(\mathrm{ft}^{3} / \mathrm{ft}^{2}\right)$

\begin{tabular}{|c|c|c|c|c|}
\hline Building Category & Total & 5-ply & 7-ply & 9-ply \\
\hline Low-Rise Residential & $0.20(0.64)$ & $0.19(0.61)$ & $0.01(0.03)$ & - \\
\hline $\begin{array}{c}\text { High-Rise } \\
\text { Residential }\end{array}$ & $0.22(0.73)$ & $0.18(0.59)$ & $0.02(0.05)$ & $0.03(0.09)$ \\
\hline Small Office & $0.19(0.62)$ & $0.19(0.62)$ & - & - \\
\hline Medium Office & $0.20(0.65)$ & $0.19(0.62)$ & $0.01(0.03)$ & - \\
\hline Large Office & $0.21(0.70)$ & $0.18(0.58)$ & $0.003(0.01)$ & $0.03(0.11)$ \\
\hline K-12 & $0.20(0.64)$ & $0.19(0.61)$ & $0.01(0.03)$ & - \\
\hline University & $0.22(0.73)$ & $0.18(0.60)$ & $0.01(0.04)$ & $0.03(0.10)$ \\
\hline Assembly & $0.21(0.70)$ & $0.19(0.61)$ & $0.02(0.06)$ & $0.01(0.04)$ \\
\hline Other Health & $0.23(0.75)$ & $0.18(0.60)$ & $0.01(0.04)$ & $0.03(0.11)$ \\
\hline Hospital & $0.23(0.74)$ & $0.18(0.59)$ & $0.01(0.04)$ & $0.03(0.10)$ \\
\hline
\end{tabular}

\section{Market penetration}

It is unrealistic to assume that CLT will attain $100 \%$ market penetration. Thus, the total demand value was reduced to account for a lower market penetration level. There are several market penetration methodologies that can be used to estimate the reduced demand. Stauder (2013) plotted the volume growth of the European market from 1995 to 2013 with future projections to 2015. He found that fifteen years after entry into the marketplace, penetration is approximately 30\%. Grasser (2015) also reported on a portion of the European market and found that in six years, the volume more than doubled from 200,000 $\mathrm{m}^{3}$ in 2008 to $500,000 \mathrm{~m}^{3}$ in 2014. Schickhofer (2015) applied Gartner's Hype Cycle to CLT to show the expected market penetration over time.

For this study, the market diffusion model presented by Beyreuther et al. (2016) was applied to the total CLT demand. Stauder (2013) and Beyreuther et al. (2016) have similar penetration numbers, with a higher rate of adaptation in the early years using the method proposed by Beyreuther et al. (2016). The Beyreuther et al. model is based on past 
wood products adoption in the US market and accounts for codes, engineering, and manufacturing in the adoption process. The baseline scenario for this study was assumed to be year 13 or 2030, which corresponds to $24 \%$ penetration. The chosen market penetration is much greater than the $1 \%$ assumed by Bédard et al. (2010) and the 5 to $15 \%$ range used by Karacabeyli and Douglas (2013) and Stauder (2013). Market penetration is a difficult value to set, and therefore demand numbers at multiple levels are included in the results. These CLT adoption numbers are based on the introduction of CLT into the market and use by customers based on cost, ease of installation, and other CLT and panelized construction attributes. However, if a CLT company is integrated with building design and/or construction, CLT adoption in the marketplace may be more rapid.

\section{Western North American CLT demand}

To expand the geographic scope of our analysis beyond the Northwest US, which encompasses the majority of the production capacity, to western North America, which provides the basis for the consumptive capacity, we calculate and then apply the Northwest per capita demand to regional population projections. Population for each of the Northwest states as well as future projections were acquired at the county level (State of Oregon 2013; Hyer 2018; State of Montana 2018; State of Washington 2018). The 2030 population values were utilized for demand projections. Idaho's data did not extend past 2025; therefore, the provided data was projected linearly to the target year. The 2030 population values and the $24 \%$ market penetration CLT demand for both low-rise multifamily housing scenarios are reported in Table 2. This CLT demand divided by the total 2030 population is defined as the CLT per capita factor. The CLT per capita factors for the four states and the Northwest US region are listed in Table 2.

Table 2. Northwest State and Regional Population, CLT Demand ( $\left.\mathrm{m}^{3} / \mathrm{yr}\right)$ Rounded to the Nearest $100 \mathrm{~m}^{3}$ Reduced to $24 \%$ Market Penetration and CLT per Capita Factor ( $\mathrm{m}^{3} /$ person)

\begin{tabular}{|c|c|c|c|cc|}
\hline \multirow{2}{*}{ Location } & \multirow{2}{*}{$\begin{array}{c}\text { Total 2030 } \\
\text { Population }\end{array}$} & \multicolumn{2}{|c|}{$\begin{array}{c}\text { Total with no multifamily } \\
\text { low-rise }\end{array}$} & \multicolumn{2}{|c|}{$\begin{array}{c}\text { Total with 1/3 multifamily } \\
\text { low-rise }\end{array}$} \\
\cline { 3 - 6 } & & $\begin{array}{c}\text { CLT } \\
\text { Demand }\end{array}$ & $\begin{array}{c}\text { CLT per } \\
\text { capita } \\
\text { factor }\end{array}$ & $\begin{array}{c}\text { CLT } \\
\text { Demand }\end{array}$ & $\begin{array}{c}\text { CLT per } \\
\text { capita } \\
\text { factor }\end{array}$ \\
\hline Washington & $8,503,000$ & 82,700 & 0.010 & 98100 & 0.012 \\
\hline $\begin{array}{c}\text { Oregon } \\
\text { Idaho }\end{array}$ & $4,768,000$ & 44,200 & 0.009 & 51800 & 0.011 \\
Montana & $2,035,000$ & 18,600 & 0.009 & 20800 & 0.010 \\
\hline $\begin{array}{c}\text { Northwest } \\
\text { US }\end{array}$ & $1,156,000$ & 8,100 & 0.007 & 9900 & 0.009 \\
\hline
\end{tabular}

It was assumed that CLT demand would be greatest in areas with a higher population. Therefore, all counties with a population of fewer than 50,000 people in 2030 were excluded from the demand projections. For Oregon and Washington, more than 90\% of the population lives in counties with more than 50,000 residents. Montana and Idaho are more rural states, and counties with populations above 50,000 account for a much smaller fraction of the total population at $62 \%$ and $73 \%$, respectively. The CLT demand was only assigned to counties meeting the population minimum, which means that the CLT demand for each state was reduced. 
The detailed information provided by the 7PP allowed for calculation of the CLT per capita factors. The projections included in the 7PP are not readily available for all locations. However, CLT produced in the Northwest US is unlikely that it will all stay within the region. Therefore, 2030 population projections, at a county level were obtained for the western US, defined as any US state that includes or is west of the Rocky Mountains (Hardcastle 2011; Blaich 2015; Perlich et al. 2017; State of Arizona 2018; State of Wyoming 2019; State of California 2020; State of Colorado 2020). Following the line of states included from the US, population data for British Columbia, Alberta, and Saskatchewan, Canada, subdivided into regional districts, are also included in the western North American demand estimates (Alberta Government 2020; BCStats 2020; Statistics Canada 2020a; Statistics Canada 2020b). The populations were reduced to include only counties or regional districts with at least 50,000 people in 2030. The average CLT per capita factor for the Northwest US was used to estimate the possible CLT demand for the entire western North American region. It should be noted that this factor is based on CLT buildings designed to meet the Seattle building code and uses the 7PP building projects for the Northwest US. In addition, the adoption of CLT may not occur quickly outside of the primary study region. The demand estimate outside of the Northwest US is speculative but provides a general scale to the potential western North American CLT demand.

\section{CLT Supply}

As with demand, the CLT supply is considered here from the top-down beginning with existing mass timber panel facilities and an exploration of what full capacity production might encompass. The supply data is followed with data on the existing lumber production facilities where production is disaggregated to include lumber grades suitable for use in CLT and those that are not.

\section{Existing CLT Production Capacity}

There are existing CLT facilities in the Northwest US and SW Canada that are included in the supply and demand discussion. Production capacities were determined for current regional producers using a combination of company news releases and personal communication with company representatives. This data has varying levels of detail for both production volume and the number of shifts required to attain the reported volumes. The provided data were normalized to represent two levels of production: 2 shifts and 3 shifts. As a baseline and unless otherwise specified, all volumes reported are for 2-shifts. Volumes that a company reports, without information on the number of shifts were all assumed to be 2-shifts, as this is the most common operating schedule discussed in personal communications. In addition, all production volumes were rounded to the nearest 1000 $\mathrm{m}^{3} / \mathrm{yr}$.

The Northwest US has four CLT facilities currently operating with additional production capacity in British Columbia, Canada. There is also a mass plywood panel (MPP) facility operating in Oregon that sells product that will directly compete in the same market. SmartLam North America has two operational CLT facilities. The first one built is located in Columbia Falls, MT and has a reported yearly capacity of $70,000 \mathrm{~m}^{3}$, which is assumed to be met in 2 shifts. The second US SmartLam facility is located in Dothan, Alabama and is omitted from this analysis because of the distance from the western North American markets. The DR Johnson Wood Innovations mill in Riddle, Oregon has a capacity of approximately $28,000 \mathrm{~m}^{3} / \mathrm{yr}$ (Huffman 2020). The Katerra facility, located in Spokane Valley, Washington, has a capacity of $185,000 \mathrm{~m}^{3} / \mathrm{yr}$, with a large portion of the 
product expected to leave the Norhtwest US region to be used in Katerra construction jobs (Katerra 2019). The Vaagen Timbers CLT facility that operates in Colville, Washington has an approximate capacity of $25,000 \mathrm{~m}^{3} / \mathrm{yr}$ of mass timber (Vaagen 2020). Depending on orders going forward, Vaagen estimates that approximately $70 \%$ of the Vaagen production will be CLT, or $18,000 \mathrm{~m}^{3} / \mathrm{yr}$ (Vaagen 2020). Sturcturlam, located in Penticton, $\mathrm{BC}$ is reported to have the same capacity as the Montana SmartLam facility, $70,000 \mathrm{~m}^{3} / \mathrm{yr}$, assumed to be manufactured in two shifts. Also located in British Columbia, Kalesnikoff can produce $50,000 \mathrm{~m}^{3} / \mathrm{yr}$ of mass timber (Sorensen 2019). The split between products will vary based on orders, but $35,000 \mathrm{~m}^{3} / \mathrm{yr}$ of CLT is a realistic estimate (Warren 2020). The total CLT industry capacity for two shifts is nearly $406,000 \mathrm{~m}^{3} /$ year, which increases to just over $600,000 \mathrm{~m}^{3} / \mathrm{yr}$ if the existing mills choose to run three shifts.

Freres Lumber manufactures MPP, a product that competes directly with CLT that has passed the mass timber code requirements for use in buildings up to eighteen stories tall. Freres is located in Lyons, Oregon and will compete for a share of the market assessed in this paper, with a capacity of $96,000 \mathrm{~m}^{3}$ (Basl 2020). However, MPP does not compete for lumber, as it is made from veneer. The impact of this product on the veneer product is beyond the scope of this project. Table 3 lists the 2-shift and 3-shift production values used in this analysis for both the CLT mills and the MPP mill.

Table 3. Estimated Western North American CLT and MPP Production Capacity Rounded to the Nearest $1000 \mathrm{~m}^{3} / \mathrm{yr}$ for Facilities Operating Two or Three Shifts

\begin{tabular}{|c|c|c|c|}
\hline Company & Location & Two Shift Capacity & $\begin{array}{c}\text { Three Shift } \\
\text { Capacity }\end{array}$ \\
\hline DR Johnson & Riddle, OR & 28,000 & 42,000 \\
\hline Katerra & Spokane Valley, WA & 185,000 & 278,000 \\
\hline SmartLam & Columbia Falls, MT & 70,000 & 105,000 \\
\hline Vaagen Timber & Colville, WA & 18,000 & 27,000 \\
\hline Kalesnikoff & Castlegar, BC & 35,000 & 53,000 \\
\hline Structurlam & Penticton, BC & 70,000 & 105,000 \\
\hline CLT Total & $\begin{array}{c}\text { Western North } \\
\text { America }\end{array}$ & 406,000 & 609,000 \\
\hline Freres Lumber & Lyons, OR & 96,000 & 144,000 \\
\hline $\begin{array}{c}\text { Mass Timber Panel } \\
\text { Total }\end{array}$ & $\begin{array}{c}\text { Western North } \\
\text { America }\end{array}$ & 502,000 & 753,000 \\
\hline
\end{tabular}

\section{Lumber Supply}

Latta et al. (2018) provided a database of lumber mills in the Northwest. For this research, each mill was reviewed to ensure that it was a lumber production facility that: is at an appropriate scale (i.e. portable sawmills and specialty producers were removed), is operational, processes softwood, has a dry kiln, and is not a stud mill. After removing facilities that do not meet the requirements for manufacturing lumber for CLT, eighty-one facilities remained in the study region (a list of facilities is available from the corresponding author upon request). The initial database (Latta et al. 2018) included production volume at many mills; however, where volumes were not included, they were determined as accurately as possible from company websites or the Big Book 2017. The species breakdown for each mill was estimated from company websites, Big Book 2017, and the Oregon Forest Industry Directory 2014 database. If no specific source was available, the regional species breakdown values for coastal and inland locations from Western Wood Products Association 2016 (WWPA) were applied. 
The Latta et al. 2018 data also included lumber mills outside of the Northwest US. The proximity of Northwest US and Southwest Canada sited CLT mills require the inclusion of Canadian softwood lumber as a probable feedstock. Fifty-two mills were identified in British Columbia and Alberta that meet the requirements outlined above. In addition, the DR Johnson mill located in southern Oregon could theoretically purchase lumber from northern California, which has seven mills that meet the constraints. Lumber from outside of the Northwest US was quantified following the same methods used for the regional lumber.

After determining the volume of each species available for purchase at each facility, the volume was partitioned by grades. The structural design of the archetype buildings was based on Structurlam's Crosslam ${ }^{\circledR}$ CLT manufactured with all No. 2 spruce-pine-fir (SPF) (Structurlam 2016). The controlling property for the archetype building was compression parallel; both Douglas-fir and hem-fir have superior compression parallel design values and were thus assumed to be an acceptable species for inclusion in CLT production in this application (NDS 2015). PRG 320-2018 allows for different species in adjacent CLT layers, but not within a layer. Although sorting lumber at a facility adds a layer of complexity, the assumption was made that this is a realistic operational choice to meet volume demands; the authors did not want to limit plant locations with a single species assumption, although some facilities may make this choice.

It was further assumed that only No. 2, nominally $2 \times 6$ lumber was purchased. The grade was required for compression parallel, and a single width was chosen to simplify material handling. The WWPA (2016) data provided the percent No. $2 \&$ better, 2x6 lumber for coastal Douglas-fir, inland Douglas-fir larch, coastal hem fir, and inland hem fir. SPF is primarily an inland species classification, and it was assumed that the percent of acceptable lumber was the average of the two inland species classifications. It should be noted that this value did not vary greatly between the classifications or locations; the range provided was 23 to $27 \%$.

The estimated annual volumes for lumber meeting the specifications for this study at each lumber facility were estimated. However, it is recognized that each mill cuts a different amount of each species classification, board size, and lumber grade each year depending on the logs harvested, and thus, the numbers reported are estimates only.

\section{RESULTS AND DISCUSSION}

The demand for CLT, as well as the rate that this demand will increase, will help determine the success of CLT in the US. It is unlikely that CLT will ever capture $100 \%$ of the potential market identified in this paper; however it is plausible that the demand could meet or exceed this value by expanding the building classifications chosen for CLT construction. While demand from developers is needed to assure production capacity, that demand likely will not grow unless manufacturers enter the market and establish reliable supply chains. However, over-saturation could result from too many facilities starting at once. If facilities fail from lack of demand in the early stages, it could discourage adding supply even as the demand surpasses capacity. This risk can be mitigated by vertically integrated firms that satisfy their own development needs with production. 


\section{Western North American CLT Demand}

The average CLT demand reported is for $24 \%$ market penetration, which is predicted to occur in 2030 (Beyreuther et al. 2016). This market penetration was applied to the average new construction demand from 2015 to 2035 for the Northwest US and using the average CLT per capita factors for western North America (Fig. 2). The predicted demand is used to determine the difference between the existing supply and the average demand of CLT and the adequacy of the regional lumber supply.

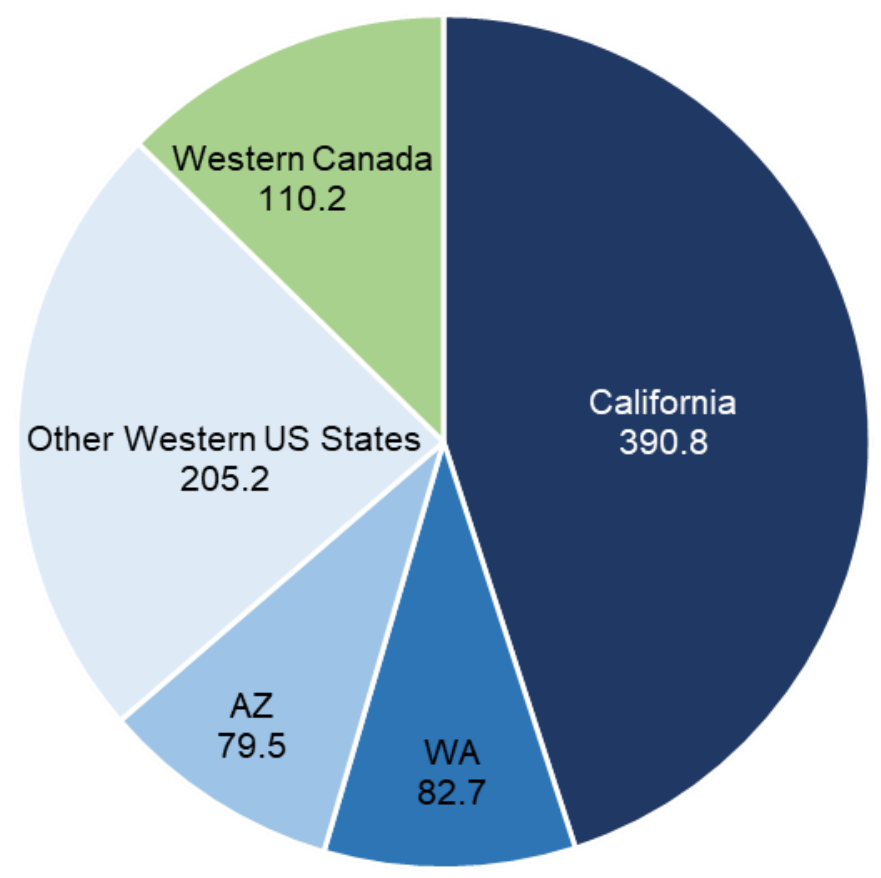

Fig. 2. CLT demand (thousand $\mathrm{m}^{3} / \mathrm{yr}$ ) for western North American locations with no low-rise multifamily demand

Demand follows population centers, with major urban centers dominating the demand. It should be noted that with the exception of the areas surrounding Vancouver, BC, Seattle, WA, and Portland, OR, the majority of the predicted demand is outside of the CLT production region. These markets will be needed to allow existing manufacturing facilities to run at full capacity for the next few years. However, transportation costs increase with the increased CLT shipping distances to job sites, resulting in either an increase in CLT cost or decrease in profit margin. In addition, gaining building code acceptance into these additional markets will require varying levels of time and effort. The most substantial potential western market is California, with a population roughly twice that of the entire Northwest US region in 2019 (United States Census Bureau 2020). Although California is a critical market, it has not adopted the 2021 IBC code, making the use of CLT a localized building code decision.

The growth in demand for CLT will vary depending on the market diffusion timeframe. The market diffusion model presented by Beyreuther et al. (2016) was combined with the average Northwest US CLT per capita factor for the no low-rise multifamily scenario, calculated from the archetype buildings, the 7PP new construction data for the Northwest, and western North American projected population numbers (Dolan et al. 2019, NPCC 2016) (Fig. 3). Although the immediate demand numbers are low, product demand will be substantial by 2030 . Demand will be greater if any of the low-rise 
multifamily residential market or commercial construction outside of the assumed categories are targeted.

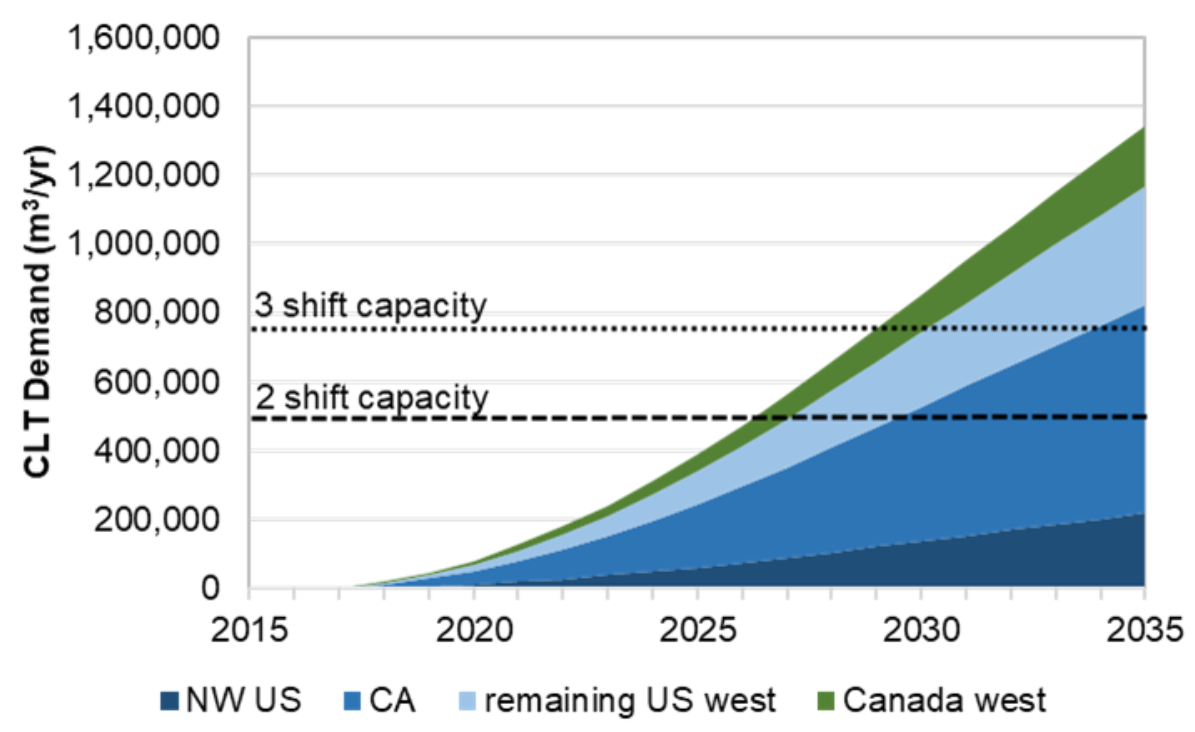

Fig. 3. CLT demand curves for the Northwest US, California, remaining US west, and western Canada adapted from Beyreuther et al. 2016 with penetration numbers in $\mathrm{m}^{3} / \mathrm{yr}$. Dashed lines are the combined CLT and MPP capacities for existing mills producing for either 2 or 3 shifts.

\section{Western North American CLT Supply}

The volume of mass timber panel supplied by the manufacturers listed in Table 3, is higher than the predicted demand for CLT and MPP prior to 2027 for the scenario with no low-rise multifamily construction utilizing manufacturing two shifts. The date move further out for three shifts to 2029. If the low-rise multifamily scenario that includes onethird of the demand is chosen, mass timber panel demand meets the capacity one year earlier, in 2026 for 2 shifts and 2028 for three shifts.

Figure 3 demonstrates that the supply of CLT and MPP production in the NW US and $\mathrm{BC}$ will need to be sold outside of the CLT production region for all of the current facilities to be successful. Katerra, described as a "high-tech construction firm" is a vertically integrated company, and the production from their facility could be utilized internally at locations outside of the Northwest (Ester 2017). However, securing the California market is critical if extended transportation costs are to be avoided. The map shown in Fig. 4 illustrates the CLT demand at the county level for the region and the location of each facility. Counties with darker grey are demand centers with southern California having the highest values. Following the California demand center is Phoenix, Las Vegas, Seattle and Vancouver, BC.

Beyreuther et al. (2016) divided the CLT market into subcategories that are expected to enter the market at different rates. Wall applications are expected to be adopted more slowly than floor and roof diaphragm elements, shifting the timeline for when the demand equals the current supply further back. If the "no low-rise multifamily" scenario is held constant, but the volume of CLT used in walls is removed, the yearly demand volume drops by 19\%. Beyreuther et al. (2016) and Ganguly et al. (2017) both proposed a Northwest US market demand in 2035 of $187,000 \mathrm{~m}^{3}$, which is based on new construction of multifamily housing and office buildings with unknown CLT use factors. 
Mass Timber Facilities

CLT MPP

Mass Timber Production $\left(\mathrm{m}^{3} / \mathrm{yr}\right)$

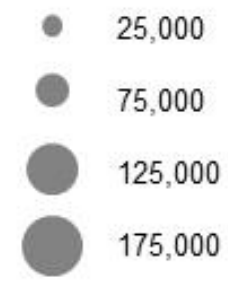

Lumber Mills

CLT Spec Production $\left(\mathrm{m}^{3} / \mathrm{yr}\right)$

$$
\begin{aligned}
& 2,000 \\
& \text { - } 30,000 \\
& \text { - } \quad 60,000 \\
& \text { - } \quad 90,000
\end{aligned}
$$

\section{Mass Timber Panel Demand} Demand $\left(\mathrm{m}^{3} / \mathrm{yr}\right)$

$\square \begin{aligned} & <500 \\ & 50,000 \\ & 100,000 \\ & 200,000 \\ & >350,000\end{aligned}$

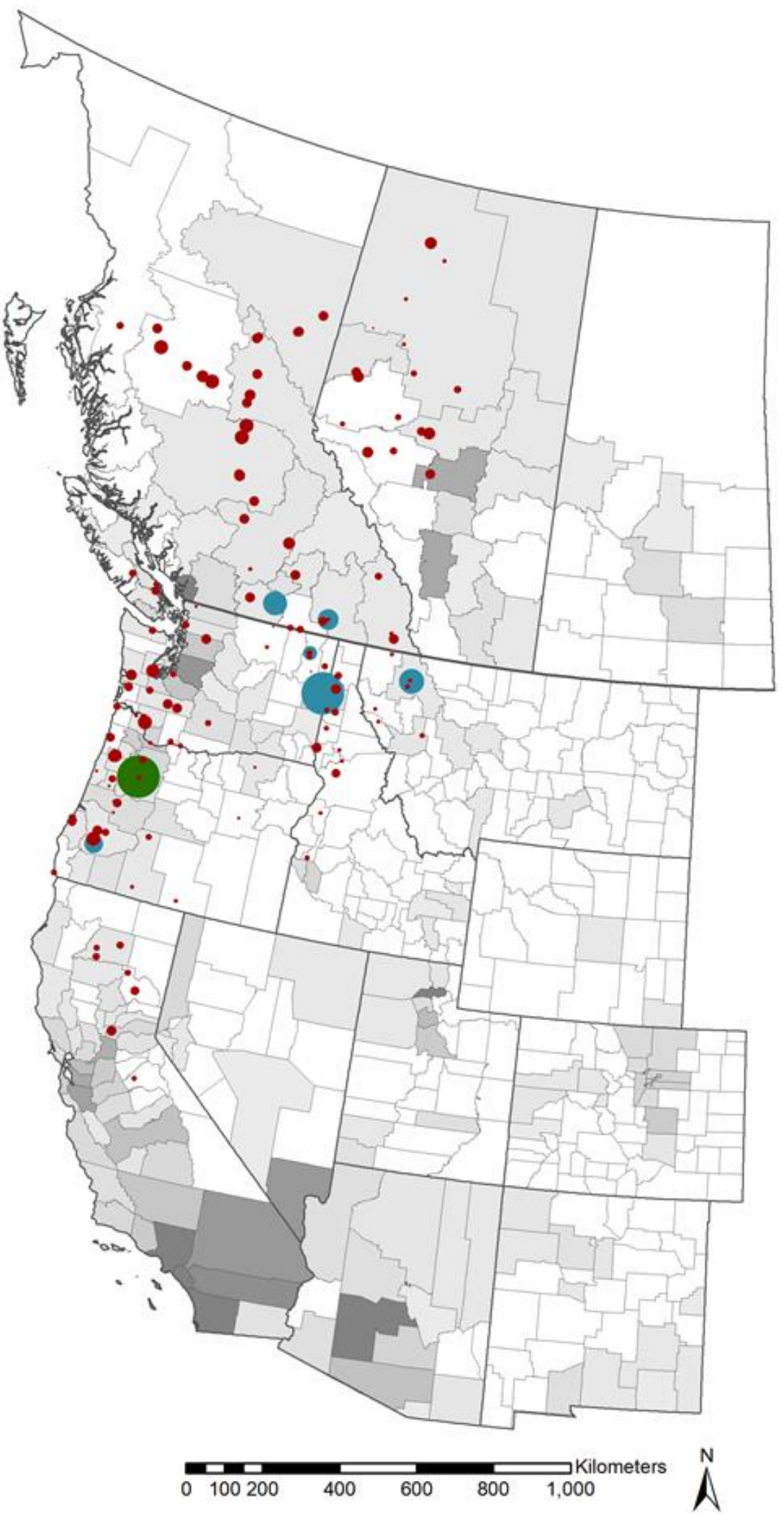

Fig. 4. Western North American CLT 2030 demand, CLT and MPP production and lumber mills 
The present work predicts a more optimistic demand of $218,000 \mathrm{~m}^{3}$ for the same region, with an expanded market, but is still short of the supply for the next 6 or more years. However, we acknowledge that CLT can be used in applications and locations not included in the present analysis, and some of these facilities are still in the start-up process and are unlikely to have high production numbers.

\section{Lumber Supply}

The lumber eligible for CLT production in the present study is assumed to be No. $2 \&$ better, kiln dried, coastal Douglas-fir, SPF, and Hem-fir. The current Northwest production volume per year of the lumber that meets these requirements is estimated to be 3.4 million $\mathrm{m}^{3}$. Based on the locations of existing CLT facilities, Canadian lumber volumes from BC, and Alberta and lumber from northern California are also included. These additions raise the total volume of acceptable lumber to 11.4 million $\mathrm{m}^{3}$. For the baseline CLT market penetration of $24 \%$, the western North American CLT demand will use approximately $8.8 \%$ for the no low-rise residential construction scenario and $10.3 \%$ for the one-third low-rise residential construction scenario of the chosen lumber. However, if only the existing CLT facilities are considered and they all run two or three shifts, they utilize $1.6 \%$ or $1.8 \%$ of the applicable lumber, respectively. It is likely that the current CLT production is lower as new facilities ramp production and add shifts as demand grows. The map in Fig. 4 shows CLT demand at a county level and on-specification sawmill capacity. Many lumber mills have contracts for lumber, making it unrealistic to believe that a new manufacturer will be able to buy all of the on-specification lumber produced at any single facility. This means that CLT producers will have the simplest time sourcing lumber if they are associated with a lumber producer, have contracts for material, or are located near multiple lumber facilities.

While neither $1.6 \%$ nor $1.8 \%$ is an overwhelming amount of lumber, this lumber already has a market and if the future CLT demand is met, approximately $10 \%$ of the onspecification lumber will be consumed. If CLT manufacturers purchase this amount of lumber without additional sawmill capacity coming online, lumber prices will likely increase. If the regional lumber capacity is increased to meet this demand, the lumber that does not meet CLT specification, nearly three-quarters of the lumber cut, will also need to be sold. For the species categories included in this study, the amount of No. 2 and better lumber produced ranges from 80 to $84 \%$ (WWPA 2016). The remaining 16 to $20 \%$ of the material is comprised of lower grades, short lengths and miscellaneous cuts. Without a demand increase for the additional No. 2 and the less desirable lumber, the CLTspecification lumber may have an additional cost increase to cover the increased production without increased demand for the lumber that does not meet the CLT specifications.

\section{CONCLUSIONS}

A methodology for quantifying cross-laminated timber (CLT) demand based on projected multifamily residential and commercial building construction was presented using data from the Northwest US. The defined methodology was then applied to western North America to demonstrate the demand with a $24 \%$ market penetration. This estimated demand was compared to current CLT manufacturing capacity and lumber supply.

1. The western North American CLT demand was estimated to be between 0.8 and 1.0 million $\mathrm{m}^{3} / \mathrm{yr}$ using projected new multifamily and the selected commercial buildings, 
archetype building designs, anticipated market penetration and population density reduction.

2. The annual CLT demand is expected to grow through 2030, with demand centers following population density resulting in high demand located in California.

3. Regional lumber use could reach $10 \%$ of the applicable species, grade, and dimension before 2030 without adding additional facilities or capacity, which could impact lumber prices. The resulting price and production implications are an area that would benefit from additional research.

4. The existing CLT facilities, with the addition of the MPP, are able to meet or surpass the western North American demand until at least 2026. The possibility for oversupply could mean that facilities operate less than 2 shifts, ship CLT west of the Rocky Mountains, sell CLT into applications not covered in our analysis or curtail production.

5. The methods for quantifying CLT demand presented in this paper can be applied outside of the study region using projected construction and population in conjunction with existing lumber production data. For the greatest accuracy, each location will need specific CLT use factors calculated to meet local building codes and lateral load requirements.

6. A stochastic analysis that encompasses ranges of CLT supply, CLT demand and lumber supply is a logical next step to quantify a variety of scenarios.

\section{ACKNOWLEDGMENTS}

This research was funded through Grant 15-DG-11062765-708 by the U.S. Forest Service, Wood Innovation Grant Program.

\section{REFERENCES CITED}

Abramson, P. (2015). " $20^{\text {th }}$ Annual College Construction Report: National Statistics, Building Trends \& Median Costs. February 2015," College Planning \& Management, (webcpm.com), Accessed 13 March 2018.

Alberta Government (2020). Alberta Population Projections, 2020-2046 - Alberta, Census Divisions and Economic Regios - Data Tables, https://open.alberta.ca/opendata/alberta-population-projections-2020-2046-albertacensus-divisions-and-economic-regions-data-tables\#summary), Accessed 12 October 2020.

ANSI/APA PRG 320 (2018). "American National Standard: Standard for PerformanceRated Cross-Laminated Timber," APA - The Engineered Wood Association, Tacoma, WA, USA.

Basl, A. (2020). Structural Engineer at Freres Lumber Co., Inc., Personal Communication on 19 March 2020.

BCStats (2020). British Columbia - Population Projections, (http://eadiv.state.wy.us/pop/wyc\&sc40.htm), Accessed 12 October 2020.

BECK (2015). "California Assessment of Wood Business Innovation Opportunities and Markets (CAWBIOM): Phase II Project Summary Report: Feasibility Assessment of 
Potential Business Opportunities," The National Forest Foundation. (https://www.nationalforests.org/assets/pdfs/Phase-II-Report-MASTER-1-4-16.pdf), accessed 7 November 2017.

Bédard, P., Fournier, F., Gagnon, S., Gingras, A., Lavoie, V., and Robichaud, F. (2010). Manufacturing Cross-Laminated Timber (CLT) Technological and Economic Analysis (Report No. 201001259-3257AAM), FPInnovations, Pointe-Claire, QC, Canada.

Beyreuther, T., Ganguly, I., Hoffman, M., and Swenson, S. (2016). "CLT Demand Model for the Pacific Northwest," (https://forterra.org/wp-content/uploads/2017/02/PacificNW-CLT-Demand-Study-December-2016.pdf), accessed 16 October 2017.

Big Book (2017). Big Book: The Buyers and Sellers Directory of the Forest Products Industry, Random Lengths Publications, Inc., Eugene, OR, USA.

Blaich, J. (2015). "New Mexico Annual Social and Economic Indicators Statistical Abstract for Data Users," New Mexico Department of Workforce Solutions, Bureau of Economic Research and Analysis, Albuquerque, New Mexico, United States.

Breneman, S., Timmers, M., and Richardson, D. (2019). "Tall Wood Buildings in the 2021 IBC Up to 18 Stories of Mass Timber," WoodWorks ${ }^{\mathrm{TM}}$ Wood Products Council, (https://www.woodworks.org/wp-content/uploads/wood_solution_paper-TALLWOOD.pdf), accessed 17 March 2020.

Clemans, T., Kenney, D., Brickman, J., Mundorff, K., Tokarczyk, J., Kauffman, M., Claflin, C., Shannon, D., Welker, A., Greene, D., et al. (2017). “Advanced Wood Product Manufacturing Study for Cross-Laminated Timber Acceleration in Oregon and SW Washington, 2017: A Catalytic Project of the Pacific Northwest Manufacturing Partnership," Oregon Best, (http://oregonbest.org/fileadmin/media/Mass_Timber/Accelerating_CLT_Manufactur ing_in_Oregon__SW_Washington_2017__Oregon_BEST_.pdf), accessed 17 August 2017.

Crespell, P., and Gagnon, S. (2010). “Cross laminated timber: A primer,” FPInnovations, (https://fpinnovations.ca/media/factsheets/Documents/cross-laminated-timber-theboook.pdf), accessed 24 October 2016.

Dolan, J. D., Wilson, A., Brandt, K., Bender, D. A., and Wolcott, M. P. (2019). "Structural design process for estimating cross-laminated timber use factors for buildings," BioResources 14(3), 7247-7265. DOI: 10.15376/biores.14.3.7247-7265

Espinoza, O., Buehlmann, U., Laguarda-Mallo, M.F., and Trujillo, V.R. (2016). "Identification of research areas to advance the adoption of cross-laminated timber in North America," BioProducts Business 1(5), 60-72. DOI: 10.22382/bpb-2016-005.

Ester, B. (2017). "Massive factory planned for CLT lumber components in Washington State," Woodworking Network. (https://www.woodworkingnetwork.com/news/woodworking-industry-news/massivefactory-planned-clt-lumber-components-washington-state), accessed 18 March 2020.

FPInnovations (2011). The Value Proposition for Cross-Laminated Timber, (http://www.fpac.ca/wp-content/uploads/publications/Future_of_forestry/Value-CLT2011_NABC_anaylisfinal.pdf), accessed 17 October 2016.

Ganguly, I., Beyreuther, T., Swenson, S., and Eastin, I. (2017). "Forecasting the demand for Cross Laminated Timber (CLT) in the Pacific Northwest," CINTRAFOR News: Center for International Trade in Forest Products.

Grasser, K. K. (2015). Development of Cross Laminated Timber in the United States of America, Master's Thesis, University of Tennessee, Knoxville, TN, USA. 
Hardcastle, J. (2011). "Nevada County Population Projections 2010 to 2030," Nevada State Demographer's Office, (https://tax.nv.gov/uploadedFiles/taxnvgov/Content/TaxLibrary/Nevada-CountyPopulation-Projections-2010-to-2030.pdf), Accessed 7 October 2020.

Hedmond, S. (2018). "Oregon becomes first state to allow mass timber buildings over six stories high," Construction Junkie, (https://www.constructionjunkie.com/blog/2018/8/24/oregon-becomes-first-state-toallow-mass-timber-buildings-over-six-stories-high), accessed 17 March 2020.

Huffman, L. (2020). Technical Director at DR Johnson Wood Innovations. Personal communication on 20 March 2020.

Hyer, J. (2018). "County Pop Projections.xlsx," Idaho Department of Labor, Research and Analysis Bureau, Personal communication on 16 March 2018.

ICC (2015). “2015 International Building Code,” International Code Council, Inc., Country Club Hills, Illinois, United States.

ICC (2020). "International Codes-Adoption by State," International Code Council, Inc., (https://www.iccsafe.org/wp-content/uploads/Master-I-Code-Adoption-Chart-July2020-PDF.pdf), accessed 14 July 2020.

Karacabeyli, E., and Douglas, B. (2013). "CLT Handbook: U.S. Edition,” FPInnovations (Special Publication SP-529E), Pointe-Claire, QC, Canada.

Katerra (2019). “Katerra Celebrates Mass Timber Factor Opening,” Katerra. (https://www.katerra.com/2019/09/23/katerra-mass-timber-factory-opens/), accessed 12 March 2020.

Latta, G., Baker, J., and Ohrel, S. (2018). "A land use and resource allocation (LURA) modeling system for projecting localized forest $\mathrm{CO}_{2}$ effects of alternative macroeconomic futures," Forest Policy and Economics 87(2018), 35-48. DOI: 10.1016/j.forpol.2017.10.003.

Mohammad, M., Gagnon, S., Douglas, B. K., and Podesto, L. (2012). “Introduction to cross laminated timber," Wood Design Focus 22(2).

Muszyński, L., Hansen, E., Fernando, S., Schwarzmann, G., and Rainer, J. (2017). "Insights into the global cross-laminated timber industry," BioProducts Business 2(8), 77-92. DOI: $10.22382 / \mathrm{bpb}-2017-008$

NDS (2015). "NDS® Supplement, Design Values for Wood Construction 2015 Edition," National Design Specification®, American Wood Council.

NEEA (2014). "Northwest Commercial Building Stock Assessment: Final Report," Northwest Energy Efficiency Alliance.

NEEA (2015). "2014 Northwest Commercial Building Stock Assessment APPENDIX AAA, Combined CBSA Building Characteristic Summary Tables," Northwest Energy Efficiency Alliance. Updated June 2015.

Oregon Forest Industry Directory (2014). "Oregon Forest Industry Directory,” Oregon State University, (http://www.orforestdirectory.com/categories/productsproduced/lumber), accessed 3 January 2018.

Pahkasalo, R., Aurenhammer, P., Bartolmé, O., and Gaston, C. (2014). "Value-Added Wood Products UNECE/FAO Forest Products Annual Market Review, 2013-2014," Geneva: UNECE/FAO Forestry and Timber Section. (https://www.unece.org/fileadmin/DAM/timber/publications/FPAMR-2014final.pdf), accessed 17 May 2018.

Perlich, P., Hollingshaus, M., Harris, E., Tennert, J., Hogue, M. (2017). “Utah’s Long- 
Term Demographic and Economic Projections Summary," Policy Institute: The University of Utah. (https://gardner.utah.edu/wp-content/uploads/Projections-BriefFinal-Updated-Feb2019.pdf), Accessed 6 October 2020.

Schickhofer, G. (2015). "Glued Wood Products for Structural Use: Cross Laminated Timer - Idea Product Building Technique," Presentation at $3^{\text {rd }}$ European Forest Week - SILVA2015.

SmartLam (2020). SmartLam North America, (https://www.smartlam.com/), Accessed 12 March 2020.

Smith, D., and Larson, K. (2017). "Washington Mill Survey 2016: Series Report \#24," Washington State Department of Natural Resources.

(https://www.dnr.wa.gov/publications/em_obe_2016_mill_survey_final.pdf?na0fa) accessed 27 November 2017.

Sorensen, J. (2019). "New B.C. mass timber plant coming on stream in 2020," Journal of Commerce by ConstructConnect ${ }^{\circledR}$.

(https://canada.constructconnect.com/joc/news/technology/2019/05/new-b-c-masstimber-plant-coming-stream-

2020\#: :text=The\%20Kalesnikoff\%20Lumber\%20mill\%20has,Canada\%2C\%20the \%20U.S.\%20and\%20Japan.), Accessed 21 October 2020.

State of Arizona (2018). Arizona Department of Administration, Office of Employment and Population Statistics. (https://www.azcommerce.com/oeo/population/populationprojections/), Accessed 7 October 2020.

State of California (2020). State of California Department of Finance. (http://www.dof.ca.gov/forecasting/demographics/projections/), Accessed 6 October 2020.

State of Colorado (2020). Colorado Information Marketplace, Population Projections in Colorado (https://data.colorado.gov/Demographics/Population-Projections-inColorado/q5vp-adf3), Accessed 9 October 2020.

State of Montana (2018). State of Montana Census \& Economic Information Center. (http://ceic.mt.gov/Maps/Demographics/Population/PopProjections_StateTotalsPage), accessed 16 March 2018.

State of Oregon (2013). "Forecasts of Oregon's County Populations and Components of Change, 2010 - 2050," State of Oregon Office of Economic Analysis, Department of Administrative Services. Last updated March 2013, (www.oregon.gov/das/OEA/Documents/County_forecast_March_2013.xls), accessed 16 March 2018.

State of Washington (2018). "Growth Management Act Population Projections for Counties: 2010 to 2040, Medium Series," State of Washington Office of Financial Management, (https://ofm.wa.gov/washington-data-research/populationdemographics/population-forecasts-and-projections/growth-management-act-countyprojections/growth-management-act-population-projections-counties-2010-2040-0), accessed 16 March 2018.

State of Wyoming (2019). Wyoming Department of Administration and Information, Economic Analysis Division. (http://eadiv.state.wy.us/pop/wyc\&sc40.htm), Accessed 7 October 2020.

Statistics Canada (2020a). Population and Dwelling Count Highlight Tables, 2016 Census. 
(https://www12.statcan.gc.ca/census-recensement/2016/dp-pd/hlt-fst/pd$\mathrm{pl} /$ Table.cfm?Lang=Eng $\& \mathrm{~T}=501 \& \mathrm{SR}=1 \& \mathrm{~S}=46 \& \mathrm{O}=\mathrm{A} \& \mathrm{RPP}=50 \& \mathrm{PR}=47)$, Accessed 12 October 2020.

Statistics Canada (2020b). Table 17-10-0057-01 Projected population, by projection scenario, age and sex, as of July 1 (x1,000). DOI:10.25318/1710005701-eng.

Stauder, C. (2013). "Cross-Laminated Timber," https://static1.squarespace.com/static/559921a3e4b02c1d7480f8f4/t/585c32fa6a4963 601460c3f0/1482437399758/Stauder.pdf, Accessed 24 October 2016.

Structurlam (2016). "CrossLam Design Guide v3.0 - USA," Structurlam, (http://www.structurlam.com/wp-content/uploads/2016/10/Structurlam-US-DesignGuide-final-LR.pdf), accessed 9 March 2018.

United States Census Bureau (2020). "U.S. and world population clock," (https://www.census.gov/popclock/), accessed 26 March 2020.

WA SBCC (2020). "2018 Code Effective Date extended to February 1, 2021", Washington State Building Code Council (SBCC), (https://sbcc.wa.gov/news/2018code-effective-date-extended-february-1-2021), accessed 14 July 2020.

Warren, M. (2020) Sales and Marketing Specialist at Kalesnikoff Mass Timber, Personal Communication on 13 October 2020.

Washington Forest Protection Association (WFPA) (2018). "Washington state to allow mid and high-rise mass-timber buildings," (https://www.prnewswire.com/news-releases/washington-state-to-allow-mid-andhigh-rise-mass-timber-buildings-300760329.html), accessed 17 March 2020.

Western Wood Products Association (WWPA) (2016). 2016 Western Lumber Production Statistics for Analysis, Portland, OR, USA.

Vaagen, R. (2020). C.E.O. at Vaagen Timbers, Personal Communication on 23 March 2020.

Article submitted: July 21, 2020; Peer review completed: Sept. 19, 2020; Revised version received and accepted: December 9, 2020; Published: December 11, 2020.

DOI: $10.15376 /$ biores.16.1.862-881 